\title{
Terms in the control and supervisory process: new in legislation
}

\author{
Elena $V$. Beliakovich \\ Law Institute of the Peoples` Friendship University of Russia, Moscow, Russia \\ Commercial Court of Chelyabinsk Region, Chelyabinsk, Russia
}

\begin{abstract}
Federal Law of 31 July 2020 No. 248-FZ On State Control (Supervision) and Municipal Control in the Russian Federation that entered into force on 1 July 2021 changed the concept of control and supervisory process, including in terms of its temporal regulation. The paper considers this Law in the context of the established terms as temporal elements of the control and supervisory process. The paper addresses new temporal ideas of the legislator in comparison with the previous legislation on control and supervisory process. The classification of terms in the control and supervisory process is proposed. The author suggests that the concentration of temporality in the normative regulation of control and supervisory activities increases and the legislator focuses on a more detailed time regulation of the control and supervisory process. It is concluded that only law enforcement practices will show whether the optimal balance is achieved between the terms and the quality of control and supervisory activities.
\end{abstract}

\section{Introduction}

Legal life affected by law is permeated with a variety of temporal categories, which measure time by significant legal events and determine the rhythm and pace of legal reality [1]. P.M. Rabinovich states that law regulates not time as such, but the temporal parameters of activity such as duration, rate, etc., and serves as one of the means of managing time [2]. Terms as an element of legal temporology are universal and play a significant role in legal regulation, including that in the framework of the most important type of state activity - state control and supervision.

Federal Law No. 248-FZ of 31 July 2020 On State Control (Supervision) and Municipal Control in the Russian Federation (hereinafter Law No. 248-FZ) [3] that entered into force on 1 July 2021 changed the concept of the control and supervisory process. The analysis of laws and regulations through the prism of the terms stipulated by it as the temporal elements of the control and supervisory process shows a more detailed regulation of time indicators and the corresponding novels.

The terms in the mechanism of legal regulation of the institution should be recognized as an effective means of achieving orderliness, organization, and stability of the legal system [4]. The terms in the control and supervisory process are the objectification of time in law and permeate the entire control and supervisory process. Figuratively speaking, it forms a time frame that limits the actions of participants in the relations of state control (supervision). The terms streamline the control and supervisory process and ensure its stability, certainty, predictability and consistency of procedural actions. As for temporal parameters, the terms set the rhythm, pace, rate of the control and supervisory process, and give it dynamism and, in general, provide 'temporal rhythms of the state and law' [5].

\section{Principle of efficiency in control and supervisory legislation}

At present, time is recognized as one of the most valuable human resources. Time is approached more and more consciously and carefully, the pace of social life is constantly increasing, and, accordingly, society requires the increased pace of public processes, including those in the control and supervision process.

The values of the state and society are most clearly manifested in principles. F. Engels noted that 'principles are not applied to nature and human history, they are abstracted from them; not nature and humanity conform to the principles, but, on the contrary, the principles are correct because they correspond to nature and history' [6]. Tempora mutantur, et nos mutamur in illis [7].

Law No. 248-FZ indicates that the legislator accepted the request for the efficiency of control and supervisory procedures and paid much more attention to the temporal elements compared to the previous Federal Law No. 294-FZ of 26.12.2008 On protection of the rights of legal entities and individual entrepreneurs in the exercise of state control (supervision) and municipal control (hereinafter Law No. 294-FZ) [8]. 
One of the main temporal achievements of Law No. 248-FZ should be recognized as the normative consolidation of the principle of efficiency (Art. 14), which consolidates the rate of the control and supervisory process by setting the optimal short term for all its participants. However, the principle of efficiency will be effective only if the optimal balance of time duration and quality of the control and supervisory process is ensured.

Professor A. Zuckerman proposed three factors for measuring justice that exhibit a compromise in any judicial system: the search for the correct solution (truth), the duration of the trial and its cost [9]. These factors seem to be applicable to the control and supervisory process. It is emphasized that the optimality of the term is ensured by the pace at which 'the attained rate does not affect the quality of the process and vice versa' [10].

Thus, the principle of efficiency implies that the need for the increased rate should not decrease the quality of the control and supervisory process. Moreover, the principle of efficiency should be based on the reality of fulfillment of the established terms to prevent its illusory shortening. However, only law enforcement practices will show whether an optimal balance has been achieved between the terms provided for by law and the quality of control and supervisory activities.

\section{General temporal novels of legislation in the field of control and supervisory activities}

Art. 15 'Terms' included in Law No. 248-FZ confirms that the legislator recognizes the importance of the institution of terms in the control and supervisory process, although it contains only one Art. 86 'Calculation of terms'.

This norm implies a classic approach that is widespread in the legislation of various branches of law to determining the terms through classification: 1) terms are established by law or determined by the control and supervisory authority, 2) terms are determined by a date (event) or a period.

The legislator uses the following time units in Law No. 248-FZ:

- hour (at least 24 hours),

- calendar day (used once in p. 5, Art. 40, Law No. 248-FZ),

- working days (basic time unit by law),

- month (used once in p. 6, Art. 51, Law No. 248-FZ) - year (used quite often).

The most frequently used evaluative temporal categories is 'immediately', in some cases - 'at once'. At the same time, p. 12, Art. 66, Law No. 248-FZ, defines the temporal characteristics of the 'immediately' category - within twenty-four hours after receiving the relevant information.

Art. 86 of Law No. 248-FZ provides general rules for calculating terms, which raises the question of the feasibility and objective need to consolidate a general theoretical approach to calculating terms in the absence of any features in calculating terms in the control and supervisory process.

The novelty is the consolidation of the duties of an inspector and prohibitions of a temporal nature in Law No. 248-FZ, namely:

- obligation to timely and fully exercise the powers granted by law (par. 2, p. 1, Art. 29),

- obligation to comply with the established terms for control (supervisory) activities and control (supervisory) actions (par. 11, p. 1, Art. 29),

- prohibition to require from the controlled person to submit documents and data earlier than the date of the control (supervisory) activities (par. 8, Art. 37),

- prohibition to exceed the established terms for control (supervisory) activities (par. 10, Art. 37).

As noted above, Law No. 248-FZ includes a significant number of temporal elements that regulate control and supervisory activities. M.I. Baytin and V.K. Babayev report that 'scientific classification as a logical-subject, creatively analytical processing of accumulated knowledge and its results streamlines the accumulated knowledge about the studied subject and serves as a prerequisite for its further comprehensive study' [11].

The classification as a method of scientific knowledge to study the terms of the control and supervisory process suggests that the terms provided in Law No. 248-FZ depending on their purpose in legal regulation can be divided into two types:

1) term as a temporal tool that determines the dynamics of the control and supervisory process (for example, the frequency of scheduled control (supervisory) activities, the term of the audit),

2) term as a legal basis for control (supervisory) activities (for example, the expiration date for execution of the decision of the supervisory authority).

In turn, the term as a legal basis for control (supervisory) activities depending on the location on the timescale can be divided into:

- due term - the due date for the control (supervisory) activities included in the plan for the control (supervisory) activities (that is, it is associated with the beginning of the time period),

- expired term - expiration of the date for the execution of the decision of the control (supervisory) body to eliminate the revealed violation of mandatory requirements (that is, consolidation at the end of the time period on the time scale).

\section{New in the control and supervisory process - new terms}

The introduction of fundamentally new procedures by the legislator within the framework of control and supervision activities established new terms.

1) Consolidation of pre-trial appeal against decisions of the control (supervisory) body, and actions (inaction) of its officials is important and expected, especially in the judicial system.

Law No. 248-FZ provides for the term for filing a complaint against the decision of the control 
(supervisory) body, and actions (inaction) of its officials - 30 calendar days (p. 5, Art. 40), and against the order of the control (supervisory) body -10 working days ( $p$. 6, Art. 40).

However, the legislator's approach to the use of different time units (working and calendar days) does not seem entirely logical, although a uniform calculation can be used for uniformity.

Moreover, there is no objective need to establish different terms for appealing against an order, a decision of the control (supervisory) body, or actions (inaction) of its officials.

It should be noted that in court (Ch. 24 of the APC RF and Ch. 22 of the CAS RF) a single procedural period is established for appealing against both non-normative legal acts and decisions, and actions (inaction). By the analogy, it seems more expedient to establish a single term for pre-trial appeal in the framework of the control and supervisory process.

The total period for consideration of a complaint is limited to 20 working days from the date of its registration with the possibility of extending it in exceptional cases for a similar period (p. 2, Art. 43).

The procedure for pre-trial appeal is regulated by the legislator and the following terms are established:

- permission of the application to suspend the execution of the contested decision of the control (supervisory) body -2 working days,

- sending a decision to suspend or refuse to suspend the contested decision -1 business day,

- making a decision to refuse to consider a complaint - 5 working days,

- submission of additional documents by the person -5 working days,

- the period for considering the complaint is suspended for a period of not more than 5 working days from the moment the request for additional information and documents is sent to the person,

- posting a decision based on the results of consideration of a complaint in the personal account -1 working day.

2) Law No. 248-FZ provides for the possibility of postponing the control and supervisory procedure if the person is not available for the period necessary to eliminate the relevant circumstances (p. 8, Art. 31).

Provisions on various types of control provide for different cases, upon the occurrence of which it is possible to postpone the conduct of a control and supervisory measure. As a general rule, the relevant circumstances include: temporary incapacity for work; stay on a business trip, vacation in another locality; the imposition of an administrative penalty in the form of administrative arrest, the election of a preventive measure against a suspect in a crime in the form of a recognizance not to leave, detention, house arrest; the onset of force majeure circumstances; introduction of a high alert or emergency situation throughout the territory of the Russian Federation or in part of it; the presence of circumstances requiring an immediate presence in another place during the control and supervisory measure.

The burden of proving the existence of the circumstances of the objective impossibility of being present during the control and supervisory measure lies with the controlled person. In turn, the control (supervisory) body establishes the existence of these circumstances on the basis of the submitted documents, and also determines the period for which the control and supervisory measure is postponed. It seems that this period can be determined both by a calendar date (for example, until August 30, 2021), and an indication of an event (for example, the termination of temporary disability).

3) The periodicity of the scheduled activities is introduced by the legislator depending on the assignment of objects of control to certain risk categories: from 2 event per year to 1 event per 6 years; regarding objects of control of the low-risk category, planned control and supervision activities are not carried out (Art. 25, Law No. 248-FZ).

The legislator, introducing the frequency of scheduled control and supervision activities for each risk category, with the exception of low risk, establishes a time interval for the frequency. So, for objects of extremely high risk category, the maximum frequency is provided: not less than 1 and not more than 2 events per year; for objects of high or significant risk - average frequency: at least 1 event in 4 years and not more than 1 event in 2 years; for objects of medium and moderate risk - the minimum frequency: at least 1 event in 6 years and not more than 1 event in 3 years.

In addition, p. 6 , Art. 25 of Law No. 248-FZ provides for the possibility of establishing the periodicity of the scheduled control (supervisory) activities within the framework of other time periods or certain events.

As part of the procedure for organizing the scheduled control (supervisory) activities, the period for coordinating the annual plan is shortened: previously, these actions were carried out from September 1 to December 31; at present - from October 1 to December 15.

4) The duration of the documentary audit is shortened by the legislator - no more than 10 working days (p. 7, Art. 72, Law No. 248-FZ). Previously, this period lasted 20 working days. At the same time, the approach to calculating this period is changed: the 10-day period for the documentary audit does not include the time period from the moment the person is sent a request to submit the necessary documents until the moment the documents are submitted.

The advantage of the new legal norm is shortening of the overall period of documents verification. However, since the period from the moment the person is sent the request to submit the necessary documents to the moment of their submission is excluded, the actual duration of 'the verification state' may exceed 20 working days provided earlier by Law No. 294-FZ that can lead to the illusory shortening of the term.

5) 10 working days are provided for the on-site inspection (p. 7, Art. 73, Law No. 248-FZ). In addition, the consolidated term for the on-site inspection at a small enterprise attains 50 hours, and at a micro-enterprise it amounts to 15 hours.

The normative consolidation of the term for 
conducting the on-site inspection at the enterprise operating in the territories of several constituent entities of the Russian Federation, which is established separately for each branch, representative office or production facility, seems to be positive.

Previously, Law No. 294-FZ (part 4 of article 13) provided for a 60-day period for verification as a whole for a legal entity, including branches, representative offices and separate subdivisions. Initially, when interpreting this rule of law, the courts proceeded from the fact that the 60-day period is calculated in relation to each individual constituent entity of the Russian Federation, and not in Russia as a whole. Subsequently, the Supreme Court of the Russian Federation formulated a legal approach, according to which the limitation of 60 working days applies as a whole to the legal entity, including branches, representative offices and separate divisions, and not to a certain territory of the legal entity's activity. Undoubtedly, the specified normative regulation of the calculation of the deadline created certain obstacles for conducting an audit if a legal entity had many divisions (for example, federal chains of grocery supermarkets).

6) The category of a reasonable term is introduced by the legislator in the regulation of control and supervisory activities. Thus, par. 1, p. 2, Art. 90 of Law No. 248-FZ provides for the obligation of the control and supervisory body to indicate a reasonable term for eliminating the identified violations specified in the order.

The normative consolidation of the reasonableness of the term in the control and supervisory process is due to the integration of the relevant legal approaches from judicial practice.

The category of reasonableness of the period for elimination of the revealed violations is based on the objective sufficiency of the period established by the control and supervisory authority for the termination of the violations specified in the order. At the same time, the obligation to prove the reasonableness of the established time limit for the execution of the order is assigned to the control and supervisory body, which is not entitled to set this time limit arbitrarily, but must, when determining it, calculate the ratio of the volume of actions to be carried out and the time objectively required to perform these actions. Non-compliance of the established period with the criterion of reasonableness entails the invalidity of the prescription in the relevant part.

7) As a general rule, decisions made based on the results of the control (supervisory) procedure carried out with violations of the requirements for the organization and implementation of the state control (supervision) and municipal control, entail the invalidity of the results.

The following violations related to the temporal parameters of control and supervisory activities are stated in Art. 91 of Law No. 248-FZ:

- violation of the terms of the control (supervisory) event,

- violation of the requirement for notification of a control (supervisory) procedure if such notification is mandatory,

- violation of the periodicity of the scheduled control (supervisory) activities.

The latter is new for the control and supervisory legislation, since the periodicity of the scheduled control and supervisory activities is introduced.

8) It should be noted that positive law states both the domination of time over man and 'man's domination over time': that is, positive law is interested, on the one hand, in ways of subordinating time and, on the other hand, in the ways of controlling time [12].

Legislation on the control and supervisory process to manage time through the use of legal fictions of a temporal nature employs the mechanisms of the term suspension and restoration. Thus, Law No. 248-FZ allows the suspension of the term for the control (supervisory) procedure (p. 13, Art. 65), suspension of the term for the complaint consideration (p. 3, Art. 43), restoration of the missed term for pre-trial appeal (p. 7, Art. 40).

\section{Conclusion}

All in all, it should be noted that Law No. 248-FZ consolidates a detailed regulation of time indicators for the control and supervisory process. New terms introduced in the control and supervisory legal regulation with due regard to the need to faster public processes are imposed by the modern realities of life.

Among the main temporal novels of Law No. 248-FZ, it is necessary to note the normative consolidation of the principle of efficiency, the inclusion of a separate chapter 'Terms', the regulation of the inspector duties and prohibitions of a temporal nature, the inclusion of the category of a reasonable time, the introduction of the periodicity of the scheduled activities, and the reduction of the period of documentary and on-site inspection. With regard to the on-site inspection, both the general term and the term for individual entities (small and micro-enterprises) are established.

Despite a number of positive novels introduced by Law No. 248-FZ, it does not seem quite logical for the legislator to use different time units in the pre-trial appeal procedure, and to establish different terms for appealing an order, a decision of the control (supervisory) body, and actions (inaction) of its officials.

In addition, with regard to the exclusion of the period from the moment the person is sent the request to submit the necessary documents to the moment when the documents are submitted from the 10-day audit period, the term may be similar to that stipulated earlier by Law No. 294-FZ, or more, which may lead to the illusory shortening of the term.

It seems that the vector for efficiency set by the legislator will be effective only if the optimal balance of the terms and the quality of control and supervisory process are ensured.

\section{References}

1. E.V. Beliakovich, On conceptual approaches to understanding the category of 'legal term' (part 2), Russian judge, 5, 7 (2000). 
2. P.M. Rabinovich, Time in legal regulation (philosophical and legal aspects), Jurisprudence, 3, 19 (1990).

3. Federal Law of 31 July 2020 No. 248-FZ On State Control (Supervision) and Municipal Control in the Russian Federation.

4. E.V. Beliakovich, On conceptual approaches to understanding the category of 'legal term' (part 2), Russian judge, 5, 7 (2000).

5. Yu.M. Baturin, R.Z. Livshits, Socialist rule of law: from idea to implementation, Moscow science, 63 (1989)

6. F. Engels, Anti-Dühring: Complete works of K. Marx, F. Engels, 20, p. 34 (1961)

7. Times change, and we change with them (Latin).

8. Federal Law of 26 December 2008 No. 294-FL On
Protection of the Rights of Legal Entities al (Supervision) and Municipal Control.

9. A. Zuckerman, Assessment of cost and delay - a multinational perspective, in: Procedural Law on the Threshold of the New Millennium: XI World Congress on Procedural Law, pp. 41-42 (Wien, Universitat, 1999)

10. R.Kh. Yakupov, Procedural terms in Soviet criminal proceedings: abstract of candidate dissertation (Higher School of the USSR Ministry of Internal Affairs, 1972)

11. M.I. Baytin, V.K. Babaev, Norms of Soviet law (Saratov University Publishing House, 1987) p. 157.

12. J.-L. Bergel, General theory of law (Moscow, 2000) p. 221. 